\title{
Direct determination of nitrogen cycling rates and pathways in Arctic fjord sediments (Svalbard, Norway)
}

\author{
Thomas M. Gihring,a,1 Gaute Lavik, ${ }^{\mathrm{b}}$ Marcel M. M. Kuypers, ${ }^{\mathrm{b}}$ and Joel E. Kostkaa,* \\ a Department of Oceanography, Florida State University, Florida \\ b Max Planck Institute for Marine Microbiology, Germany
}

\begin{abstract}
Results from a study of benthic nitrogen cycling in two Arctic fjords are presented. Intact sediment core incubations were used to quantify net fluxes of dissolved inorganic nitrogen, organic nitrogen, organic carbon, and oxygen across the sediment-water interface. Rates of gross denitrification, anammox, nitrification, dissimilatory nitrate reduction to ammonium, and $\mathrm{N}_{2}$ fixation were quantified using core incubations and slurry experiments. Profiles of dissolved inorganic nitrogen in pore-water, and organic carbon and nitrogen contents in the solid phase, were also obtained. Net nitrogen losses as $\mathrm{N}_{2}$, measured directly as changes in $\mathrm{N}_{2}$ : Ar, ranged from $152 \mu \mathrm{mol} \mathrm{N} \mathrm{m}{ }^{-2} \mathrm{~d}^{-1}$ to $453 \mu \mathrm{mol} \mathrm{N} \mathrm{m}{ }^{-2} \mathrm{~d}^{-1}$. Gross denitrification, as determined using ${ }^{15} \mathrm{~N}-\mathrm{NO}_{3}^{-}$tracers, was 34-294 $\mu \mathrm{mol} \mathrm{N} \mathrm{m}{ }^{-2} \mathrm{~d}^{-1}$. Rates of anammox ranged from $10 \mu \mathrm{mol} \mathrm{N} \mathrm{m} \mathrm{N}^{-2} \mathrm{~d}^{-1}$ to $26 \mu \mathrm{mol} \mathrm{N} \mathrm{m}^{-2} \mathrm{~d}^{-1}$ and contributed 5-23\% of gross $\mathrm{N}_{2}$ generation. Nitrification rates were as high as $833 \mu \mathrm{mol} \mathrm{N} \mathrm{m} \mathrm{N} \mathrm{d}^{-1}$ and sediments were a substantial source of nitrate to the water column (169-393 $\mu \mathrm{mol} \mathrm{N} \mathrm{m}{ }^{-2} \mathrm{~d}^{-1}$ efflux). Uptake of ammonium (52-87 $\left.\mu \mathrm{mol} \mathrm{N} \mathrm{m} \mathrm{m}^{-2} \mathrm{~d}^{-1}\right)$, dissolved organic nitrogen (291-486 $\left.\mu \mathrm{mol} \mathrm{N} \mathrm{m} \mathrm{N}^{-2} \mathrm{~d}^{-1}\right)$, and dissolved organic carbon (1313-2504 $\mu \mathrm{mol} \mathrm{N} \mathrm{m} \mathrm{N}^{-2} \mathrm{~d}^{-1}$ ) were observed. Nitrogen loss from the seafloor is shown to occur at rates comparable to temperate coastal environments and the sediments provide a substantial source of nitrate to the water column of Arctic fjords. In addition, anammox is confirmed as an important pathway in Arctic marine sediments, although $\mathrm{N}_{2}$ production is dominated by denitrification.
\end{abstract}

In the Arctic Ocean, where nearly half of the seafloor is comprised of relatively shallow continental shelf, a large fraction (up to $80 \%$ ) of water column production is deposited and subsequently degraded or buried in shelf sediments (Hansell and Goering 1990; Wassmann 1991). Understanding nitrogen cycling in polar regions is imperative because the Arctic Ocean is experiencing shifts in historic trends of air temperature, ice cover, coastal upwelling, and marine primary production (Arrigo et al. 2008). However, nitrogen sinks, sources, and transformations are at present poorly understood in coastal Arctic sediments compared to their temperate or subtropical counterparts.

Previous studies of carbon and nitrogen cycling in Arctic sediments have focused primarily on quantifying overall rates of organic matter mineralization in the BeringChukchi-Beaufort Seas, Svalbard and the Barents Sea, and the coasts of Greenland (Table 1). The consensus of previous work indicates that rates of microbial activity in permanently cold sediments $\left(<2^{\circ} \mathrm{C}\right)$ are similar to warmer coastal environments and labile carbon availability is a stronger control of benthic respiration than temperature (Arnosti et al. 1998; Glud et al. 1998; Thamdrup and Fleischer 1998). In agreement with trends observed for overall benthic respiration rates, nitrogen mineralization rates in cold sediments appear comparable to temperate environments (Glud et al. 1998, 2000). Measured rates of nitrification have generally been high, particularly in areas

\section{*Corresponding author: jkostka@ocean.fsu.edu}

${ }^{1}$ Present address: Oak Ridge National Laboratory, Biosciences Division, Oak Ridge, Tennessee with surface sediment aeration by benthic fauna (Henriksen et al. 1993), consistent with evidence that nitrifying bacterial communities are well-adapted to low temperatures (Thamdrup and Fleischer 1998). Marine nitrogen fixation has gained considerable attention as an important source of bioavailable nitrogen for primary production (Karl et al. 2002), although to our knowledge, few nitrogen fixation measurements in Arctic sediments have been reported (Table 1).

Previous measurements of benthic denitrification in the Arctic using ${ }^{15} \mathrm{~N}$ tracer techniques ranged from $0 \mu \mathrm{mol} \mathrm{N}$ $\mathrm{m}^{-2} \mathrm{~d}^{-1}$ to $100 \mu \mathrm{mol} \mathrm{N} \mathrm{m}{ }^{-2} \mathrm{~d}^{-1}$ in the Barents Sea, up to $630 \mu \mathrm{mol} \mathrm{N} \mathrm{m} \mathrm{N}^{-2} \mathrm{~d}^{-1}$ in Svalbard fjords, and showed intermediate rates along the Greenland coasts (Table 1). Rates of net $\mathrm{N}_{2}$ flux were up to $2800 \mu \mathrm{mol} \mathrm{N} \mathrm{m}{ }^{-2} \mathrm{~d}^{-1}$ in the Bering-Chukchi Seas, determined using benthic chambers and core incubations coupled with measurements of $\left[\mathrm{N}_{2}\right]$ using gas chromatography or membrane inlet mass spectrometry (Devol et al. 1997; Chang and Devol 2009). Within the last decade, anammox has gained recognition as an important pathway for $\mathrm{N}_{2}$ production in coastal sediments and hypoxic zones (Dalsgaard et al. 2005) and may be particularly prevalent in cold environments (Thamdrup and Dalsgaard 2002). Rates of anammox can be measured using core incubations with ${ }^{15} \mathrm{~N}$ tracers, although in sediments with co-occurring anammox and denitrification, additional treatments and modified calculations must be applied to avoid overestimating $\mathrm{N}_{2}$ production (Risgaard-Petersen et al. 2003). Presently, the only anammox measurements for Arctic sediments were conducted along the coasts of Greenland where $\mathrm{N}_{2}$ production by anammox accounted for up to $35 \%$ of total microbial $\mathrm{N}_{2}$ production and anammox populations 
Nitrogen cycling in Svalbard sediments

Table 1. Summary of previous results from benthic carbon and nitrogen cycling studies in the Arctic Ocean.*

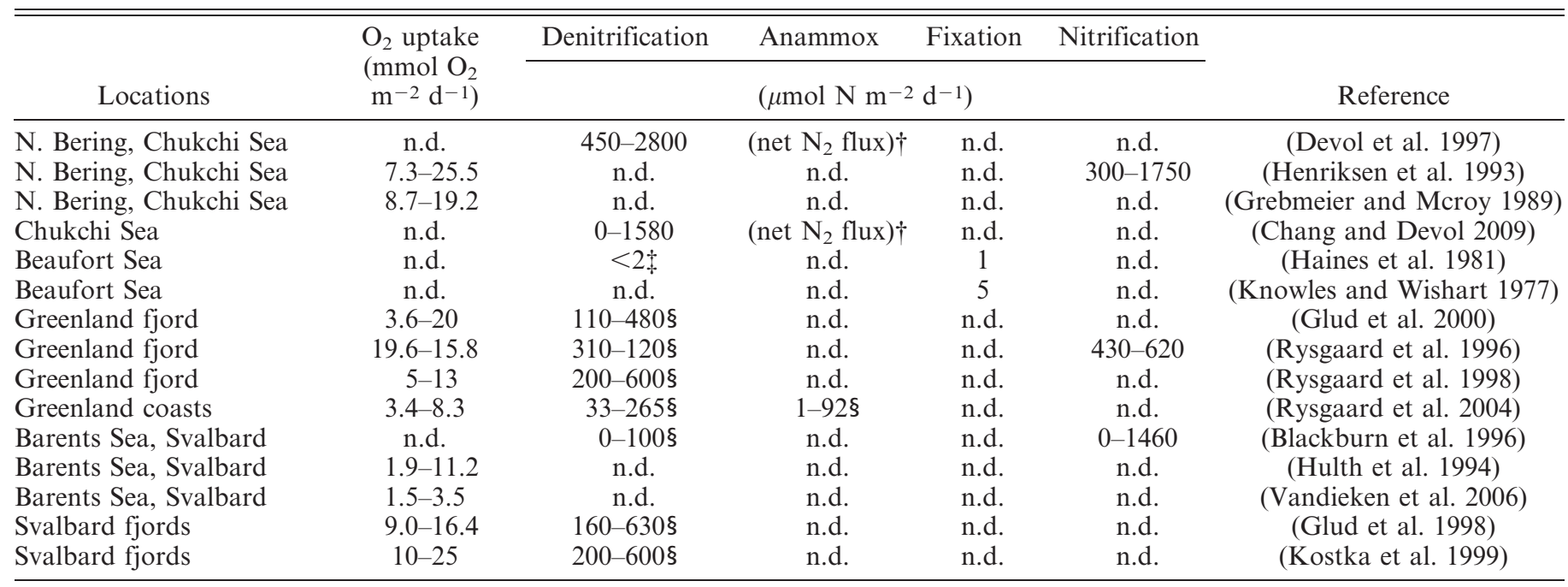

$*$ n.d. $=$ not determined.

$\dagger$ Rates from benthic flux chambers with $\left[\mathrm{N}_{2}\right]$ measurement by gas chromatography or membrane inlet mass spectrometry.

* Rates from acetylene block slurries.

$\S$ Rates from isotope pairing technique cores.

appeared to favor cold, stable conditions with high $\mathrm{NO}_{3}^{-}$ availability (Rysgaard et al. 2004).

In this study, benthic nitrogen and carbon cycling were studied in fjords of Svalbard, which is situated on the eastern edge of the Fram Strait, the major deep-water passage between the North Atlantic and Arctic Ocean (Fig. 1). Objectives of this study were: (1) to directly determine rates of net nitrogen loss as $\mathrm{N}_{2}$; (2) compare rates of gross $\mathrm{N}_{2}$ production via denitrification and anammox at two sites with dissimilar overall benthic respiration rates; and (3) quantify fluxes of nitrate, ammonium, nitrous oxide, dissolved organic nitrogen, dissolved organic carbon, and oxygen across the sediment-water interface. Although anammox rates are generally higher in organicrich coastal sediments, the overall contribution of the process to $\mathrm{N}_{2}$ production may be inversely proportional to sedimentary organic matter content (Dalsgaard et al. 2005).
We hypothesized that net $\mathrm{N}_{2}$ fluxes would be comparable to more temperate coastal sediments and the importance of anammox in $\mathrm{N}_{2}$ production would be inversely correlated with overall rates of benthic respiration. These data provide one of the most complete studies of benthic fluxes, and one of the few reports of anammox, in the Arctic.

\section{Methods}

Study sites and sampling procedures-Samples were collected during two cruises in August 2007 and 2008 onboard the Norwegian R/V FARM within two fjords along the northwestern coast of Spitsbergen, the largest island in the Svalbard archipelago (Fig. 1). Atlantic Water moving pole-ward along the western continental slope of the Svalbard islands (the West Spitsbergen Current) entrains shelf water and exchanges with bottom water in
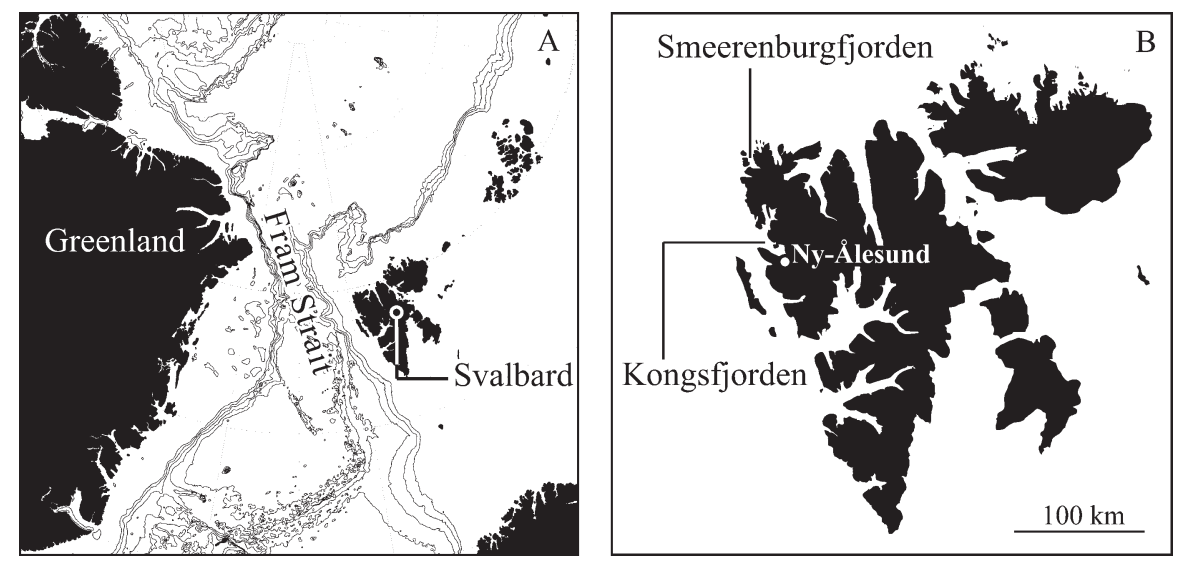

Fig. 1. (A) Bathymetric map of the North Atlantic, Barents Sea, and Arctic Ocean. (B) Locations of Kongsfjorden and Smeerenburgfjorden in the northwest of Spitsbergen Island, Svalbard. 
Table 2. Description of the sampling stations and sediment characteristics. ${ }^{*}$

\begin{tabular}{|c|c|c|c|c|}
\hline \multirow[b]{2}{*}{ Description } & \multicolumn{2}{|c|}{ Smeerenburgfjorden } & \multicolumn{2}{|c|}{ Kongsfjorden } \\
\hline & 2007 & 2008 & 2007 & 2008 \\
\hline Latitude & \multicolumn{2}{|c|}{$79^{\circ} 42.01^{\prime} \mathrm{N}$} & \multicolumn{2}{|c|}{$78^{\circ} 59.43^{\prime} \mathrm{N}$} \\
\hline Longitude & \multicolumn{2}{|c|}{$11^{\circ} 05.20^{\prime} \mathrm{E}$} & \multicolumn{2}{|c|}{$12^{\circ} 17.87^{\prime} \mathrm{E}$} \\
\hline Water depth $(\mathrm{m})$ & \multicolumn{2}{|c|}{211} & \multicolumn{2}{|c|}{51} \\
\hline Bottom-water temperature $\left({ }^{\circ} \mathrm{C}\right)$ & 2.8 & 3.3 & 1.7 & 1.8 \\
\hline Bottom-water salinity & 37.0 & 35.0 & 36.5 & 37.0 \\
\hline Bottom-water $\left[\mathrm{NO}_{3}^{-}\right](\mu \mathrm{mol} \mathrm{L}-1)$ & 3.9 & $\mathrm{n} / \mathrm{a}$ & 4.7 & $\mathrm{n} / \mathrm{a}$ \\
\hline Bottom-water $\left[\mathrm{NH}_{4}^{+}\right](\mu \mathrm{mol} \mathrm{L}-1)$ & $<0.2$ & $\mathrm{n} / \mathrm{a}$ & $<0.2$ & $\mathrm{n} / \mathrm{a}$ \\
\hline Sediment temperature $\left({ }^{\circ} \mathrm{C}\right)$ & 2.3 & 1.6 & 1.1 & 1.3 \\
\hline Sediment $\mathrm{C}_{\text {org }}$ content (dry wt $\%$ ) & $\mathrm{n} / \mathrm{a}$ & 1.45 & $\mathrm{n} / \mathrm{a}$ & 0.30 \\
\hline Sediment $\mathrm{C}: \mathrm{N}(\mathrm{mol}: \mathrm{mol})$ & $\mathrm{n} / \mathrm{a}$ & 7.2 & $\mathrm{n} / \mathrm{a}$ & 11 \\
\hline
\end{tabular}

$* \mathrm{n} / \mathrm{a}=$ not available.

Svalbard fjords (Rudels et al. 2000; Cottier et al. 2005). The northward West Spitsbergen Current then branches to either join with the Atlantic Return Current to the west or enter the Arctic Basin to the north and east (Manley 1995).

The two sampling sites, Smeerenburgfjorden and Kongsfjorden, are described in Table 2. A Haps corer (Kanneworff and Nicolaisen 1973) was used to collect sediment for sub-coring and bottom water was obtained using a Niskin bottle. Bottom-water samples for dissolved inorganic nitrogen determinations were collected directly from the Niskin bottle (2007 cruise). Sea water and cores were stored outdoors at ambient air temperature $\left(0-3^{\circ} \mathrm{C}\right)$. Sediment pore-water was collected onboard the ship's deck using Rhizon samplers (Rhizosphere Research Products), which consist of a 50-mm-length porous polymer tube (2.5$\mathrm{mm}$ diameter) connected to thin tygon tubing attached to a syringe via a Luer-Lock. Rhizons were inserted horizontally into side ports of 9.5 -cm-diameter Haps sub-cores at 1-cm depth intervals (Seeberg-Elverfeldt et al. 2005). Rhizons and syringes were rinsed once with $0.5 \mathrm{~mL}$ of extracted pore-water followed by the collection of $2 \mathrm{~mL}$ of pore-water from each depth interval; samples were frozen at $-20^{\circ} \mathrm{C}$. Carbon content and atomic $\mathrm{C}: \mathrm{N}$ of bulk sediments were determined for cores $(0-5$-cm depth) frozen on site and transported to Florida State University. Sediments were freeze-dried, homogenized by grinding with mortar and pestle, and split into two halves, one for nitrogen analyses and the other for carbon analyses. Inorganic carbon was removed from the latter samples by vapor acidification (Hedges and Stern 1984). Total nitrogen and organic carbon contents were determined using an elemental analyzer at the National High Magnetic Field Laboratory Isotope Geochemistry Facility (Tallahassee, Florida). Average coefficients of variation for triplicate C and $\mathrm{N}$ measurements were $3 \%$ and $4 \%$, respectively. Sediments at both sites had worm burrows although their density was greater at Smeerenburgfjorden.

Net fluxes of dissolved nitrogen, organic carbon, and oxygen - Intact core incubations were performed to determine the net fluxes of dissolved $\mathrm{N}_{2}, \mathrm{O}_{2}$, inorganic nitrogen, organic nitrogen, and organic carbon (Table 3). Four to six sediment cores $(9.5-\mathrm{cm}$ diameter with $10 \mathrm{~cm}$ sediment and
$10 \mathrm{~cm}$ overlying water) were incubated for each set of experiments and one to three core tubes containing only seawater were used as blank controls. Cores were preincubated by submerging them in a tank filled with site bottom water held at constant temperature in a controlled environment chamber. The water overlying each core was equilibrated with air and circulated continuously overnight using air-lift pumps (Cornwell et al. 1999). A container of bottom seawater for sample water replacement was equilibrated continuously by sparging with air. Following preincubation and equilibration, all cores were sealed with gas-tight caps fitted with sealable sampling ports. During the 2008 incubations, three of six cores from each site also received $50 \mu \mathrm{mol} \mathrm{L}-1{ }^{15} \mathrm{NO}_{3}^{-}$for measuring potential rates of dissimilatory nitrate reduction to ammonium (DNRA; expt 2 in Table 3). The water overlying each core was stirred at 70 revolutions per min using laboratory stir bars driven by an external magnet. Overlying water samples were withdrawn and replaced with air-equilibrated seawater at 6-12-h intervals for up to $60 \mathrm{~h}$.

Samples for $\mathrm{N}_{2}$ measurements were collected in gas-tight $12 \mathrm{~mL}$ Exetainer vials and preserved with $250 \mu \mathrm{L}$ of $50 \%$ (wt $\mathrm{vol}^{-1}$ ) $\mathrm{ZnCl}_{2}$. Samples for dissolved oxygen measurements were collected in $12 \mathrm{~mL}$ Exetainer vials and mixed immediately with Winkler reagents for later titrations. Samples for dissolved inorganic nitrogen (DIN; ammonium, nitrate, and nitrite) determinations were filtered immediately $(0.2 \mu \mathrm{m})$ and frozen at $-20^{\circ} \mathrm{C}$ until analysis. Filtered samples for dissolved organic carbon (DOC) and total dissolved nitrogen (TDN) were collected in combusted $\left(500^{\circ} \mathrm{C}\right.$ overnight) glass vials and were preserved by the addition of trace metal grade $\mathrm{HCl}$ to $10 \mathrm{mmol} \mathrm{L}^{-1}$ final concentration.

Rates of $\mathrm{N}_{2}, \mathrm{O}_{2}$, inorganic nitrogen, organic nitrogen, and organic carbon benthic flux in core incubations were calculated from linear regressions of concentrations as a function of time, and were normalized to sediment area by multiplying by the overlying water depth. All fluxes were corrected for the addition of sample replacement water and rates determined in water-only control experiments. Total carbon oxidation rates $\left(\mathrm{TC}_{\mathrm{ox}}\right)$ were estimated as the sum of the measured net $\mathrm{O}_{2}$ flux, plus carbon oxidation by denitrification, less the rate of $\mathrm{O}_{2}$ consumption by 
Nitrogen cycling in Svalbard sediments

Table 3. Experimental approaches used in this study, respective amendments, and corresponding rate determinations from each method.

\begin{tabular}{|c|c|c|}
\hline Experimental method & Tracer addition(s) & Rate determination(s)* \\
\hline 1. Intact cores, batch incubation & No addition & Net flux of $\mathrm{N}_{2}, \mathrm{O}_{2}, \mathrm{NO}_{3}^{-}, \mathrm{NO}_{2}^{-}, \mathrm{NH}_{4}^{+}, \mathrm{DON}$, and DOC \\
\hline 2. Intact cores, batch incubation & ${ }^{15} \mathrm{NO}_{3}^{-}$ & DNRA potential \\
\hline 3. Intact cores, destructive sampling & $15 \mathrm{NO}_{3}^{-}$ & Denitrification and anammox rate \\
\hline 4. Intact cores, destructive sampling & ${ }^{14} \mathrm{NO}_{3}^{-},{ }^{15} \mathrm{NH}_{4}^{+}, \mathrm{ATU} \dagger$ & Anammox rate \\
\hline 5. Slurry in vials & ${ }_{15} \mathrm{NO}_{3}^{-}$ & $\begin{array}{l}\text { Depth-integrated }(0-5 \mathrm{~cm}) \text { denitrification and anammox } \\
\text { potentials }\end{array}$ \\
\hline 6. Slurry in bags & ${ }^{15} \mathrm{NO}_{3}^{-}$ & $\begin{array}{l}\text { Vertical profiles of denitrification and anammox potentials } \\
\text { (1-cm-depth intervals) }\end{array}$ \\
\hline 7. Slurry in vials & Acetylene & Nitrogen fixation potential \\
\hline
\end{tabular}

$*$ DON $=$ dissolved organic nitrogen; DOC $=$ dissolved organic carbon; DNRA $=$ dissimilatory nitrate reduction to ammonium.

$\dagger$ ATU $=$ Allylthiourea.

nitrification (Canfield et al. 1993). Carbon oxidized by denitrification was calculated from the denitrification rate (determined using ${ }^{15} \mathrm{~N}$ tracers in cores; below) and the reaction of 1 mole of $\mathrm{C}$ oxidized per 0.8 moles of $\mathrm{NO}_{3}^{-}$ reduced to $\mathrm{N}_{2}$. Nitrification rates were calculated as the sum of the nitrate flux and nitrate consumed by anammox and denitrification:

$$
\begin{aligned}
\text { nitrification rate }= & \mathrm{NO}_{3}^{-} \text {flux }+\left(\mathrm{N}_{2} \text { flux } \times \mathrm{ra} \times 0.5\right) \\
& +\left[\mathrm{N}_{2} \text { flux } \times(1-\mathrm{ra})\right]
\end{aligned}
$$

where ra was the fraction of $\mathrm{N}_{2}$ production from anammox (described below) and $\mathrm{N}_{2}$ flux was the net $\mathrm{N}_{2}$ flux determined from $\mathrm{N}_{2}$ : Ar measurements. Nitrification as a fraction of net oxygen consumption was calculated as

$$
\begin{aligned}
\text { percent nitrification }= & (2 \times \text { nitrification rate }) \\
& \times\left(\text { net } \mathrm{O}_{2} \text { flux }\right)^{-1}
\end{aligned}
$$

Denitrification and anammox-Four types of sediment incubation experiments for denitrification and anammox rate determinations were designed using ${ }^{15} \mathrm{~N}$ tracers (expts 3-6 in Table 3). Two sets of intact core incubations with ${ }^{15} \mathrm{~N}$ tracers were performed for the determination of denitrification and anammox rates (expts 3,4). Incubations using ${ }^{15} \mathrm{~N}$-nitrate $\left(50 \mu \mathrm{mol} \mathrm{L} \mathrm{L}^{-1}\right)$ followed the isotope pairing technique of Nielsen (1992) as modified by Risgaard-Petersen et al. (2003). In this approach, rates of ${ }^{29} \mathrm{~N}_{2}$ and ${ }^{30} \mathrm{~N}_{2}$ production from ${ }^{15} \mathrm{NO}_{3}^{-}$are quantified and used to calculate rates of ${ }^{14} \mathrm{~N}_{2}$ production $\left(\mathrm{p}_{14}\right)$; when combined with ${ }^{15} \mathrm{~N}$ tracer slurry incubations (below), rates of anammox, and the relative contributions of anammox and denitrification to $\mathrm{p}_{14}$, can be determined. To obtain an additional estimate of anammox potential rates in intact sediments, core incubations were performed using $50 \mu \mathrm{mol} \mathrm{L}-1{ }^{15} \mathrm{~N}$-ammonium (99 atom \%), $50 \mu \mathrm{mol} \mathrm{L} \mathrm{L}^{-1}$ ${ }^{14} \mathrm{~N}$-nitrate $(99$ atom $\%$ ), and $200 \mu \mathrm{mol} \mathrm{L}-1$ allylthiourea (expt 4; Table 3). In this experiment, anammox rates were estimated by the production of ${ }^{29} \mathrm{~N}_{2}$ from the one-to-one coupling of ${ }^{15} \mathrm{NH}_{4}^{+}$and ${ }^{14} \mathrm{NO}_{2}^{-}$during anammox. Allylthiourea (ATU), a specific inhibitor of nitrification, was added to prevent the conversion of ${ }^{15} \mathrm{NH}_{4}^{+}$to nitrite or nitrate (Hall 1984). ATU has no significant effect on anammox activity in sediments or in cultures (Jensen et al. 2007).

A set of 15 cores $(3.5-\mathrm{cm}$ diameter with $15 \mathrm{~cm}$ sediment and $15 \mathrm{~cm}$ water) was incubated for each site and tracer treatment. Water overlying the sediment was removed and replaced with site bottom water amended with tracers according to the descriptions for expts 3, 4 above. The ${ }^{15} \mathrm{~N}$ labeling of $\mathrm{NO}_{3}^{-}$and $\mathrm{NH}_{4}^{+}$in the overlying water was $>$ $90 \%$ for all core incubations as determined from concentrations before and after tracer additions. Cores were sealed without gaseous headspace using rubber stoppers and the overlying water was mixed continuously by externally driven magnetic stir bars. Three cores were sacrificed at each designated time point, $(0,12,24,36$, and $48 \mathrm{~h})$ by adding $1 \mathrm{~mL}$ of zinc acetate ( $20 \% \mathrm{wt} \mathrm{vol}^{-1}$ ) to the sediment surface and gently mixing the sediment and water with a metal rod. Samples for measuring the rates of ${ }^{29} \mathrm{~N}_{2}$ $\left({ }^{14} \mathrm{~N}^{15} \mathrm{~N}\right)$ and ${ }^{30} \mathrm{~N}_{2}\left({ }^{15} \mathrm{~N}^{15} \mathrm{~N}\right)$ production were transferred to $12 \mathrm{~mL}$ Exetainers (Labco) prefilled with $250 \mu \mathrm{L}$ zinc chloride $\left(50 \% \mathrm{wt} \mathrm{vol}^{-1}\right)$. Seawater samples were filtered and frozen before and after tracer addition for later nitrate and ammonium concentration, and ${ }^{15} \mathrm{~N}:{ }^{14} \mathrm{~N}$ labeling of $\mathrm{NH}_{4}^{+}$and $\mathrm{NO}_{3}^{-}$, determinations. All denitrification and anammox core incubations were carried out in the dark within a temperature-controlled environmental chamber at the Kings Bay Marine Laboratory in Ny-Ålesund, Svalbard. Specific rates were calculated according to Eqs. 1, 2 described below.

Volumetric rates of denitrification and anammox, and the relative contribution of anammox to gross $\mathrm{N}_{2}$ production, were determined using two sets of sediment slurry experiments (Table 3). Slurries for depth-integrated rates $(0-5 \mathrm{~cm})$ were prepared in glass vials according to Thamdrup and Dasgaard (2002). Artificial sea water (ASW) was constructed at a salinity of $38(27.5 \mathrm{~g} \mathrm{NaCl}$, $5.9 \mathrm{~g} \mathrm{MgCl}_{2} \times 6 \mathrm{H}_{2} \mathrm{O}, 1.5 \mathrm{~g} \mathrm{CaCl}_{2} \times 2 \mathrm{H}_{2} \mathrm{O}, 7.2 \mathrm{~g} \mathrm{MgSO}_{4} \times$ $7 \mathrm{H}_{2} \mathrm{O}, 0.21 \mathrm{~g} \mathrm{KH}_{2} \mathrm{PO}_{4}$, and $0.76 \mathrm{~g} \mathrm{KCl}$ per liter) and was diluted with de-ionized water to match the bottom-water salinity of each site. After dilution, ASW was sparged with helium and amended with $100 \mu \mathrm{mol} \mathrm{L}^{-1}{ }^{15 \mathrm{~N}}$-nitrate $(99$ atom \%). One $\mathrm{mL}$ of homogenized sediment from $0 \mathrm{~cm}$ to $5 \mathrm{~cm}$ was added to $12-\mathrm{mL}$ Exetainers, which were then 
filled with ASW leaving no headspace. For each site, 15 vials total were incubated with three vials sacrificed at time points from $0 \mathrm{~h}$ to $48 \mathrm{~h}$. Incubations were stopped by adding $250 \mu \mathrm{L}$ of $\mathrm{ZnCl}_{2}$ and resealing the vials without headspace. Denitrification and anammox rates in slurries were calculated according to Eqs. 6, 7 described below.

Experiments to determine the volumetric rates of anammox and denitrification in a vertical profile of Smeerenburgfjorden sediment sampled in 2007 were performed using bag slurry incubations (expt 6; Table 3). Cores were sectioned at $1-\mathrm{cm}$ intervals and sediment was sealed within gas-impermeable foil bags along with heliumsparged bottom water containing $50 \mu \mathrm{mol} \mathrm{L}-115 \mathrm{~N}$-nitrate (99 atom \%). The bag slurries were incubated at $1.5^{\circ} \mathrm{C}$. Samples for measuring rates of ${ }^{29} \mathrm{~N}_{2}$ and ${ }^{30} \mathrm{~N}_{2}$ production were withdrawn from the bags at $12-\mathrm{h}$ intervals and were preserved in 5-mL Exetainers with $\mathrm{ZnCl}$ as above. Denitrification and anammox rates in slurries were calculated from ratios of excess ${ }^{29} \mathrm{~N}_{2}$ and ${ }^{30} \mathrm{~N}_{2}$ production according to Eqs. 6, 7 (below).

For incubations conducted in 2007, concentrations of excess ${ }^{29} \mathrm{~N}_{2}$ and ${ }^{30} \mathrm{~N}_{2}$ were calculated from ${ }^{29} \mathrm{~N}_{2}:{ }^{28} \mathrm{~N}_{2}$ and ${ }^{30} \mathrm{~N}_{2}:{ }^{28} \mathrm{~N}_{2}$ of helium-equilibrated headspace $(2 \mathrm{~mL})$ in Exetainers determined by gas-chromatography isotope ratio mass spectrometry. Excess ${ }^{29} \mathrm{~N}_{2}$ and ${ }^{30} \mathrm{~N}_{2}$ concentrations for incubations conducted in 2008 were calculated from dissolved ${ }^{29} \mathrm{~N}_{2}:{ }^{28} \mathrm{~N}_{2}$ and ${ }^{30} \mathrm{~N}_{2}:{ }^{28} \mathrm{~N}_{2}$ measured using a membrane inlet mass spectrometer configured and calibrated according to An et al. (2001). Rates of excess ${ }^{29} \mathrm{~N}_{2}$ $\left(\mathrm{p}_{29}\right)$ and ${ }^{30} \mathrm{~N}_{2}\left(\mathrm{p}_{30}\right)$ production were based on linear regressions of ${ }^{29} \mathrm{~N}_{2}$ and ${ }^{30} \mathrm{~N}_{2}$ concentration time series.

Rates of ${ }^{14} \mathrm{~N}_{2}$ production $\left(\mathrm{p}_{14}\right)$ in core incubations with ${ }^{15} \mathrm{NO}_{3}^{-}$tracer addition (expt 3; Table 3) were determined according to Risgaard-Peterson et al. (2003):

$$
\mathrm{p}_{14}=2 \times \mathrm{r}_{14} \times\left[\mathrm{p}_{29}+\mathrm{p}_{30} \times\left(1-\mathrm{r}_{14}\right)\right]
$$

The ${ }^{14} \mathrm{~N}:{ }^{15} \mathrm{~N}$ ratio of $\mathrm{NO}_{3}^{-}$undergoing reduction to $\mathrm{N}_{2}$ $\left(\mathrm{r}_{14}\right)$ was determined as follows:

$$
\mathrm{r}_{14}=\left[\mathrm{R}_{29} \times(1-\mathrm{ra})-\mathrm{ra}\right] \times(2-\mathrm{ra})^{-1}
$$

where $R_{29}$ was the ratio of $p_{29}$ to $p_{30}$ determined for the cores and ra was the relative contribution of anammox to gross $\mathrm{N}_{2}$ production determined in vial slurry incubations (expt 5). Gross denitrification and anammox rates within intact cores with ${ }^{15} \mathrm{NO}_{3}^{-}$tracer addition were calculated as follows:

$$
\begin{gathered}
\text { denitrification }=\mathrm{p}_{14} \times(1-\mathrm{ra}) \\
\text { anammox }=\mathrm{p}_{14} \times \mathrm{ra}
\end{gathered}
$$

Anammox potential rates in cores amended with ${ }^{15} \mathrm{NH}_{4}^{+},{ }^{14} \mathrm{NO}_{3}^{-}$, and ATU (expt 4) were estimated based on the rate of excess ${ }^{29} \mathrm{~N}_{2}$ production:

$$
\text { anammox potential }=\mathrm{p}_{29}
$$

Linear rates of $\mathrm{N}_{2}$ production over time in cores $(\mu \mathrm{mol} \mathrm{N}$ $\left.\mathrm{L}^{-1} \mathrm{~d}^{-1}\right)$ were normalized to sediment area $(\mu \mathrm{mol} \mathrm{N}$ $\mathrm{m}^{-2} \mathrm{~d}^{-1}$ ) by multiplying the production rate by the total volume of water in the core (pore-water plus overlying water) and dividing by the core area.

Rates of denitrification and anammox in vial and bag slurry incubations with ${ }^{15} \mathrm{NO}_{3}^{-}$amendments were determined using the equations of Thamdrup and Dalsgaard (2002):

$$
\begin{aligned}
\text { denitrification }=\mathrm{p}_{30} \times \mathrm{F}_{\mathrm{N}}^{-2} \\
\begin{aligned}
\text { anammox }= & \left(\mathrm{p}_{29} \times \mathrm{F}_{\mathrm{N}}^{-1}\right) \\
& -\left[\text { denitrification } \times 2 \times\left(1-\mathrm{F}_{\mathrm{N}}\right)\right]
\end{aligned}
\end{aligned}
$$

where $\mathrm{F}_{\mathrm{N}}$ was the fraction of ${ }^{15} \mathrm{~N}$ in nitrate. All rates and fluxes pertaining to nitrogen species in this study were normalized to one atom nitrogen.

Nitrogen fixation potential rates-The reduction of acetylene as a substrate analog of $\mathrm{N}_{2}$ was used to measure potential rates of nitrogen fixation (Capone 1993) for sediments collected in 2008. Slurries of sediment and artificial seawater were prepared in Exetainers as above with the exception that vials were filled to leave $6 \mathrm{~mL}$ of gaseous headspace. Acetylene was generated by the reaction of calcium carbide with water and was added to the vials at $10 \%\left(\mathrm{vol} \mathrm{vol}^{-1}\right)$ after purging the headspace with $\mathrm{N}_{2}$. Five vials per site were incubated at $1.5^{\circ} \mathrm{C}$ and were sampled periodically up to $48 \mathrm{~h}$. Triplicate control slurries, killed by the addition of $\mathrm{HgCl}_{2}$ and $\mathrm{ZnCl}_{2}$, were also incubated and sampled over time. Samples for gas analysis were withdrawn through the vial septa at each time point and the production of ethylene was measured using a gas chromatograph with a Porapak N column and flame ionization detection. Ethylene production rates in slurries were calculated based on the linear regressions of ethylene production in five replicate sediment slurries relative to three replicate killed controls. Rates of total ethylene production in the $1-\mathrm{cm}^{-3}$ wet sediment incubations were converted to aerial nitrogen fixation potential rates using a $\mathrm{C}_{2} \mathrm{H}_{2}: \mathrm{N}_{2}$ reduction ratio of 3 and a depth integration of $5 \mathrm{~cm}$ (Capone 1993).

Dissolved nitrogen, organic carbon, and $\mathrm{O}_{2}$ analysesTDN and DOC were measured using a Shimadzu TOC-5000 analyzer. Dissolved ammonium $\left(\mathrm{NH}_{4}^{+}\right)$was determined by colorimetry (Bower and Holm-Hansen 1980). Nitrate + nitrite $\left(\mathrm{NO}_{x}^{-}\right)$and nitrite $\left(\mathrm{NO}_{2}^{-}\right)$were determined by chemiluminescence after reduction with vanadium (Braman and Hendrix 1989) or iodide (Garside 1982), respectively; nitrate $\left(\mathrm{NO}_{3}^{-}\right)$was calculated as the difference between $\mathrm{NO}_{x}^{-}$and $\mathrm{NO}_{2}^{-}$concentrations. Concentrations and atom $\%{ }^{15} \mathrm{~N}-\mathrm{NH}_{4}^{+}$of samples for DNRA rate measurements were determined by high-performance liquid chromatography (Gardner et al. 1995). Dissolved organic nitrogen (DON) was calculated as the difference between TDN and DIN $\left(\mathrm{NO}_{x}^{-}+\mathrm{NH}_{4}^{+}\right)$. Dissolved $\mathrm{N}_{2}$ was measured using a membrane inlet mass spectrometer configured and calibrated according to Kana et al. (1994) with the modification of removing oxygen from the inflow gas 
upstream of the mass spectrometer using an in-line quartz column packed with copper turnings heated to $600^{\circ} \mathrm{C}$ (Eyre et al. 2002). $\mathrm{N}_{2}$ concentrations were calculated from measured $\mathrm{N}_{2}$ : Ar ratios assuming constant $\mathrm{Ar}$ concentrations (Kana et al. 1994). Samples for dissolved $\mathrm{O}_{2}$ were analyzed following each sampling time point using Winkler titration (Grasshoff et al. 1983). Mean coefficients of variation were $1.6 \%, 1.9 \%, 22 \%, 1.2 \%, 1.2 \%$, and $0.013 \%$ for $\mathrm{NH}_{4}^{+}, \mathrm{NO}_{x}^{-}, \mathrm{NO}_{2}^{-}, \mathrm{TDN}, \mathrm{DOC}$, and $\mathrm{N}_{2}$, respectively.

\section{Results}

Sediment characteristics and dissolved inorganic nitrogen profiles-Sediment carbon contents measured in 2008 (Table 2) were much lower at Kongsfjorden (0.30 dry wt $\%)$ relative to Smeerenburgfjorden (1.45 dry wt \%). Ratios of organic carbon to total nitrogen were slightly higher at Kongsfjorden (11) compared to Smeerenburgfjorden (7.2).

Rhizon samplers were used to withdraw pore-water from core profiles to avoid artifacts from sediment sectioning or squeezing (Seeberg-Elverfeldt et al. 2005). Measurements of DIN in pore-water collected from Smeerenburgfjorden sediment showed a nonlinear increase in ammonium with depth (Fig. 2). Three of the Smeerenburgfjorden profiles showed nitrate concentration peaks in the surface layers concomitant with sharp declines in ammonium, whereas the remaining profiles showed relatively constant, low nitrate levels. Pore-water from Kongsfjorden sediment had elevated nitrate concentrations near the sediment surface and increasing ammonium concentrations with depth (Fig. 2). Peaks in nitrate concentration were also observed between $4 \mathrm{~cm}$ and $6 \mathrm{~cm}$ corresponding with zones of ammonium depletion. All nitrite measurements were < $1 \mu \mathrm{mol} \mathrm{L}-1$ and there were no apparent trends in nitrite profiles from either station.

Direct flux measurements - Rate measurements determined for Smeerenburgfjorden using intact core incubations in 2007 and 2008 showed net efflux of $\mathrm{N}_{2}$ at $389 \mu \mathrm{mol}$ $\mathrm{N} \mathrm{m} \mathrm{m}^{-2} \mathrm{~d}^{-1}$ and $453 \mu \mathrm{mol} \mathrm{N} \mathrm{m}^{-2} \mathrm{~d}^{-1}$, respectively (Table 4). Oxygen uptake was $6260 \mu \mathrm{mol} \mathrm{O}_{2} \mathrm{~m}^{-2} \mathrm{~d}^{-1}$ and $6765 \mu \mathrm{mol} \mathrm{O} \mathrm{m}^{-2} \mathrm{~d}^{-1}$, respectively. Ammonium was consumed at $68 \mu \mathrm{mol} \mathrm{N} \mathrm{m}{ }^{-2} \mathrm{~d}^{-1}$ and $52 \mu \mathrm{mol} \mathrm{N} \mathrm{m}^{-2} \mathrm{~d}^{-1}$, whereas nitrate showed net efflux of $169 \mu \mathrm{mol} \mathrm{N} \mathrm{m}{ }^{-2} \mathrm{~d}^{-1}$ and $393 \mu \mathrm{mol} \mathrm{N} \mathrm{m} \mathrm{N}^{-2} \mathrm{~d}^{-1}$. Nitrification rates in batch cores were $551 \mu \mathrm{mol} \mathrm{N} \mathrm{m} \mathrm{N}^{-2} \mathrm{~d}^{-1}$ and $833 \mu \mathrm{mol} \mathrm{N} \mathrm{m} \mathrm{N}^{-2} \mathrm{~d}^{-1}$. Dissolved organic nitrogen and organic carbon fluxes both showed net uptake of $291 \mu \mathrm{mol} \mathrm{N} \mathrm{m}{ }^{-2} \mathrm{~d}^{-1}$ and $1313 \mu \mathrm{mol}$ $\mathrm{C} \mathrm{m}^{-2} \mathrm{~d}^{-1}$, respectively, in 2008 (Table 4).

Kongsfjorden core incubations conducted in 2008 showed net $\mathrm{N}_{2}$ efflux at $152 \mu \mathrm{mol} \mathrm{N} \mathrm{m}{ }^{-2} \mathrm{~d}^{-1}$ and oxygen uptake of $4041 \mu \mathrm{mol} \mathrm{O}_{2} \mathrm{~m}^{-2} \mathrm{~d}^{-1}$ (Table 4). Nitrate efflux of $261 \mu \mathrm{mol}$ $\mathrm{N} \mathrm{m}^{-2} \mathrm{~d}^{-1}$ was observed, whereas ammonium, DON, and DOC showed net consumption of $87 \mu \mathrm{mol} \mathrm{N} \mathrm{m}^{-2} \mathrm{~d}^{-1}$, $486 \mu \mathrm{mol} \mathrm{N} \mathrm{m}^{-2} \mathrm{~d}^{-1}$, and $2504 \mu \mathrm{mol} \mathrm{N} \mathrm{m}^{-2} \mathrm{~d}^{-1}$, respectively. Nitrification was calculated as $396 \mu \mathrm{mol} \mathrm{N} \mathrm{m}^{-2} \mathrm{~d}^{-1}$. Shifts in the atom percent $15 \mathrm{~N}$ of ammonium in overlying water samples were not observed at either site, indicating that dissimilatory reduction of nitrate from the overlying water was not measurable $\left(<50 \mu \mathrm{mol} \mathrm{N} \mathrm{m}^{-2} \mathrm{~d}^{-1}\right.$; Table 4$)$.
Anammox, denitrification, and nitrogen fixation ratesGross $\mathrm{N}_{2}$ production $\left(\mathrm{p}_{14}\right)$ at the Smeerenburgfjorden site, determined using ${ }^{15} \mathrm{NO}_{3}^{-}$tracer in core incubations, was $320 \mu \mathrm{mol} \mathrm{N} \mathrm{m}{ }^{-2} \mathrm{~d}^{-1}$ and $305 \mu \mathrm{mol} \mathrm{N} \mathrm{m}-2 \mathrm{~d}^{-1}$ in 2007 and 2008, respectively (see Table 5). Slurry incubations using ${ }^{15} \mathrm{NO}_{3}^{-}$tracer were used to determine the fractions of $\mathrm{N}_{2}$ production attributable to anammox (ra). For Smeerenburgfjorden sediment, anammox contributed $8 \%$ and $5 \%$ in 2007 and 2008, respectively, to total $\mathrm{N}_{2}$ production. By applying these ra values from slurries to ${ }^{29} \mathrm{~N}_{2}$ and ${ }^{30} \mathrm{~N}_{2}$ production rates in ${ }^{15} \mathrm{NO}_{3}^{-}$amended intact core incubations (Risgaard-Petersen et al. 2003), denitrification rates were calculated as $294 \mu \mathrm{mol} \mathrm{N} \mathrm{m}-2 \mathrm{~d}^{-1}$ and $289 \mu \mathrm{mol} \mathrm{N}$ $\mathrm{m}^{-2} \mathrm{~d}^{-1}$, whereas anammox was $26 \mu \mathrm{mol} \mathrm{N} \mathrm{m} \mathrm{N}^{-2} \mathrm{~d}^{-1}$ and $15 \mu \mathrm{mol} \mathrm{N} \mathrm{m} \mathrm{N}^{-2} \mathrm{~d}^{-1}$ in 2007 and 2008, respectively. Anammox estimates from ${ }^{29} \mathrm{~N}_{2}$ production in intact cores amended with ${ }^{15} \mathrm{NH}_{4}^{+}$tracer and ${ }^{14} \mathrm{NO}_{3}^{-}$, used to confirm the presence of anammox activity, were $81 \mu \mathrm{mol} \mathrm{N} \mathrm{m}{ }^{-2} \mathrm{~d}^{-1}$ and $46 \mu \mathrm{mol} \mathrm{N} \mathrm{m} \mathrm{N} \mathrm{m}^{-2} \mathrm{~d}^{-1}$ in 2007 and 2008, respectively (Table 5). Vertical profiles of anammox and denitrification activity (Fig. 4) indicated relatively constant denitrification rates throughout the $0-5-\mathrm{cm}$ profile, whereas anammox rates were highest near the surface and peaked in the 1-2$\mathrm{cm}$ interval where both nitrate and ammonium are available in pore-water (Fig. 2). Acetylene reduction assays of Smeerenburgfjorden sediment demonstrated a linear increase in ethylene produced in live slurries relative to killed controls (Fig. 5). The nitrogen fixation potential rate was $20 \mu \mathrm{mol} \mathrm{N} \mathrm{m}-2 \mathrm{~d}^{-1}$ integrated for the upper $0-5 \mathrm{~cm}$ of sediment.

At the Kongsfjorden station, $\mathrm{p}_{14}$ was $44 \mu \mathrm{mol} \mathrm{N} \mathrm{m}{ }^{-2} \mathrm{~d}^{-1}$ determined using ${ }^{15} \mathrm{~N}$-nitrate amended intact cores. The relative contribution of anammox to total $\mathrm{N}_{2}$ production (ra) at the 2008 Kongsfjorden station was $23 \%$ in ${ }^{15} \mathrm{NO}_{3}^{-}$ tracer slurry incubations (Table 5). Correspondingly, denitrification rates in cores with ${ }^{15} \mathrm{NO}_{3}^{-}$amendment were $34 \mu \mathrm{mol} \mathrm{N} \mathrm{m} \mathrm{N}^{-2} \mathrm{~d}^{-1}$, whereas anammox contributed $10 \mu \mathrm{mol} \mathrm{N} \mathrm{m} \mathrm{N}^{-2} \mathrm{~d}^{-1}$. The anammox potential rate determined from ${ }^{29} \mathrm{~N}_{2}$ production in ${ }^{15} \mathrm{NH}_{4}^{+}$amended cores was $17 \mu \mathrm{mol} \mathrm{N} \mathrm{m} \mathrm{N} \mathrm{m}^{-2} \mathrm{~d}^{-1}$. Nitrogen fixation potential rates in Kongsfjorden sediment were below detection (Table 5).

\section{Discussion}

Removal of bioavailable nitrogen through the production of $\mathrm{N}_{2}$ in coastal sediments is a major controlling factor for the marine nitrogen budget (Christensen et al. 1987; Seitzinger and Giblin 1996; Devol et al. 1997). Benthic processes affecting bioavailable nitrogen in the Arctic are particularly important as through-flow and mixing with the greater oceans can have widespread effects on global marine primary production (Yamamoto-Kawai et al. 2006). The majority of current data on nitrogen removal from Arctic sediments is derived from gross denitrification measurements at relatively few sites (Table 1). Anammox may be a major pathway for nitrogen loss from the oceans, although relatively few studies have addressed the significance of this process in benthic nitrogen removal (Thamdrup and Dalsgaard 2002; Rysgaard et al. 2004; 
Nitrite, nitrate $\left(\mu \mathrm{mol} \mathrm{L}{ }^{-1}\right)$
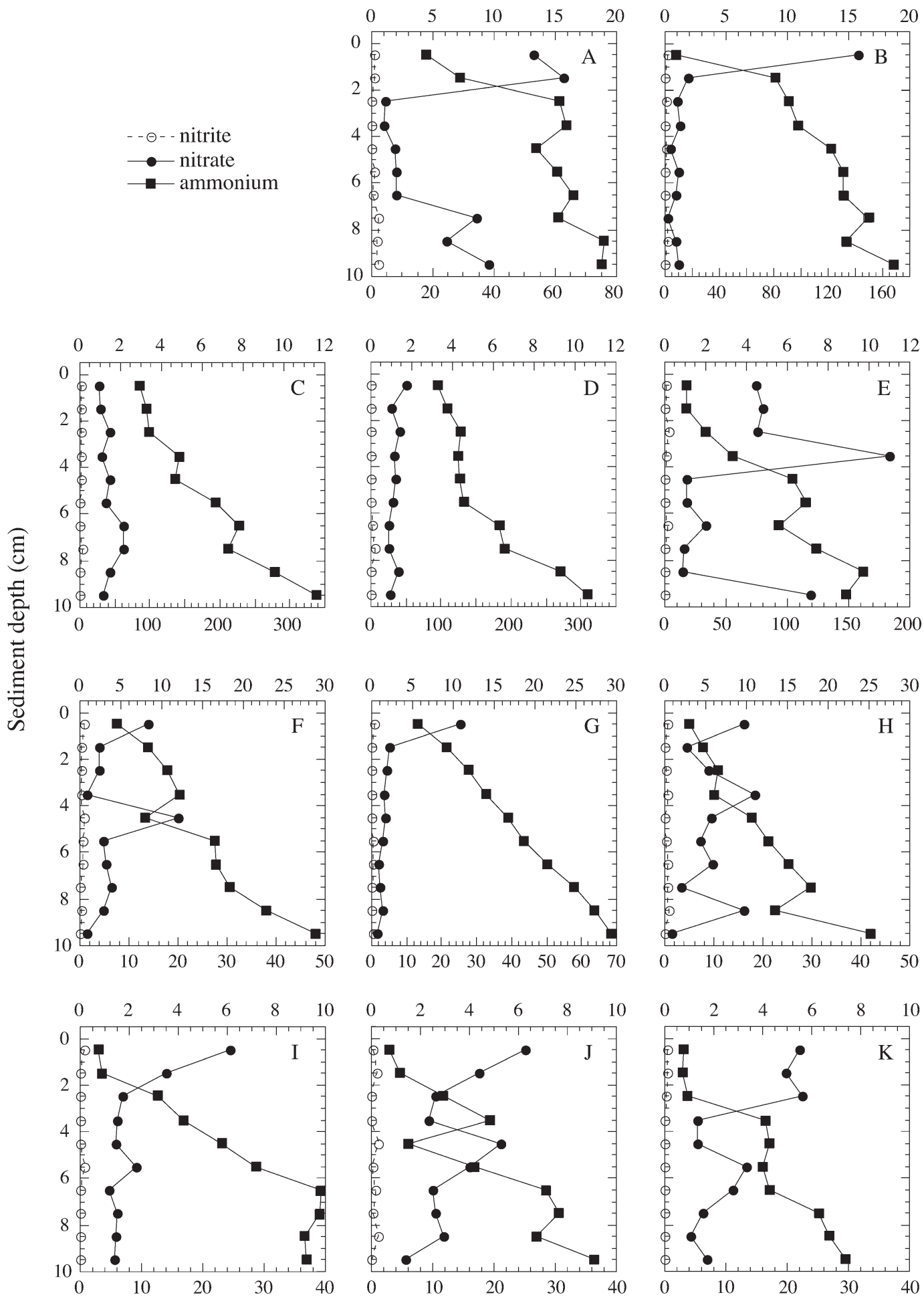

Ammonium $\left(\mu \mathrm{mol} \mathrm{L}^{-1}\right)$

Fig. 2. Profiles of pore-water nitrate, nitrite, and ammonium concentrations from (A, B) Smeerenburgfjorden 2007, (C, D, E) Smeerenburgfjorden 2008, (F, G, H) Kongsfjorden 2007, and (I, J, K) Kongsfjorden 2008. 


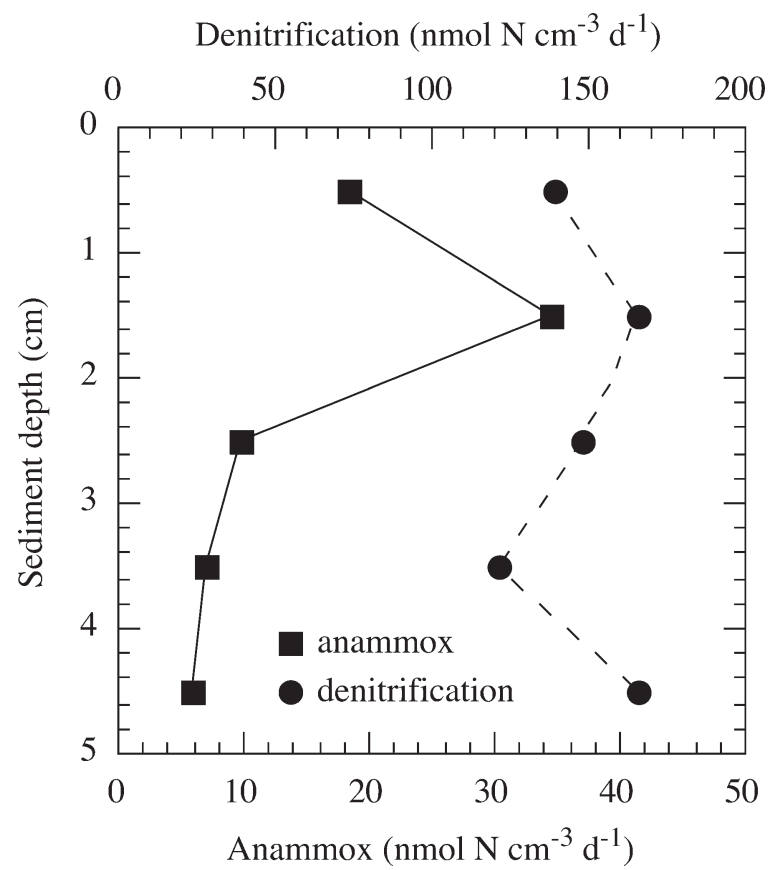

Fig. 3. Smeerenburgfjorden anammox and denitrification potential rates determined for $0-5-\mathrm{cm}$ depth intervals.

Dalsgaard et al. 2005). With the exception of data from Rysgaard et al. (2004), anammox in Arctic sediments has largely been unrecognized.

Here an integrated approach of determining net fluxes of dissolved organic and inorganic constituents, and quantifying $\mathrm{N}_{2}$ production and consumption pathways, was used to study nitrogen transformations in Svalbard fjord sediments. We hypothesized that Svalbard sediments undergo substantial loss of nitrogen in the form of $\mathrm{N}_{2}$, anammox holds a vital role in $\mathrm{N}_{2}$ generation, and the importance of anammox in $\mathrm{N}_{2}$ production would be inversely correlated with overall rates of benthic respiration. These hypotheses were supported, and new evidence on the importance of nitrification, DON and DOC fluxes, and $\mathrm{N}_{2}$ fixation in Arctic sediments was revealed.
Net and gross $\mathrm{N}_{2}$ production-Results presented here demonstrate substantial benthic $\mathrm{N}_{2}$ efflux and a direct relationship between carbon oxidation rates and total $\mathrm{N}_{2}$ production. A summary of all rates and fluxes determined in this study are shown in Fig. 5. In comparison to rates reported for other Arctic sediments, net fluxes of $\mathrm{N}_{2}$ at Smeerenburgfjorden (389-453 $\mu \mathrm{mol} \mathrm{N} \mathrm{m}^{-2} \mathrm{~d}^{-1}$ ) were below those from Bering-Chukchi Sea and were similar to rates determined along the coasts of Greenland and Svalbard (Table 1). At the Kongsfjorden site, both $\mathrm{N}_{2}$ flux and $\mathrm{O}_{2}$ consumption (a proxy for total carbon oxidation) were lower than at Smeerenburgfjorden, indicating a direct relationship between $\mathrm{N}_{2}$ production and $\mathrm{O}_{2}$ consumption at these sites. The $\mathrm{N}_{2}$ flux at Kongsfjorden $(152 \mu \mathrm{mol} \mathrm{N}$ $\mathrm{m}^{-2} \mathrm{~d}^{-1}$ ) was also lower than most rates measured from Arctic sites (Table 1). Differences between gross $\mathrm{N}_{2}$ production (sum of denitrification and anammox measured using ${ }^{15} \mathrm{~N}$-nitrate tracer) and net $\mathrm{N}_{2}$ fluxes across the sediment-water interface (Tables 4 and 5) greater than the standard errors were likely due to physical and biological heterogeneity amongst cores or the slight alteration of denitrification rates with nitrate additions in ${ }^{15} \mathrm{~N}$ tracer cores (Eyre et al. 2002). Denitrification was $4 \%$ of total carbon oxidation at Smeerenburgfjorden (Table 5), which is comparable to the contribution of denitrification to carbon oxidation determined for a wide range of coastal environments (mean $=12 \%$ ) compiled by Seitzinger and Giblin (1996). In contrast, denitrification comprised $<1 \%$ of carbon oxidation at Kongsfjorden (Table 4). Results from both sites parallel previous observations that denitrification is not a predominant pathway of carbon oxidation in Svalbard fjord sediments (Glud et al. 1998; Kostka et al. 1999). However, contrasting $\mathrm{N}_{2}$ efflux at the two sites, and the direct relationship between $\mathrm{N}_{2}$ production and oxygen consumption, suggests denitrification and anammox rates are affected by overall benthic respiration rates.

Nitrate availability was clearly not limiting $\mathrm{N}_{2}$ production given the strong release of $\mathrm{NO}_{3}^{-}$relative to $\mathrm{N}_{2}$, particularly at the Kongsfjorden site where $\mathrm{NO}_{3}^{-}$efflux was almost double the $\mathrm{N}_{2}$ efflux. Thus, heterotrophic nitrate respiration to $\mathrm{N}_{2}$ is likely controlled by the availability of labile organic matter, as observed for other

Table 4. Mean net fluxes and rates of nitrification measured using batch core incubations. Values in parenthesis denote the standard deviation of replicate cores, or the lower limit of detection, and the number of replicate cores.

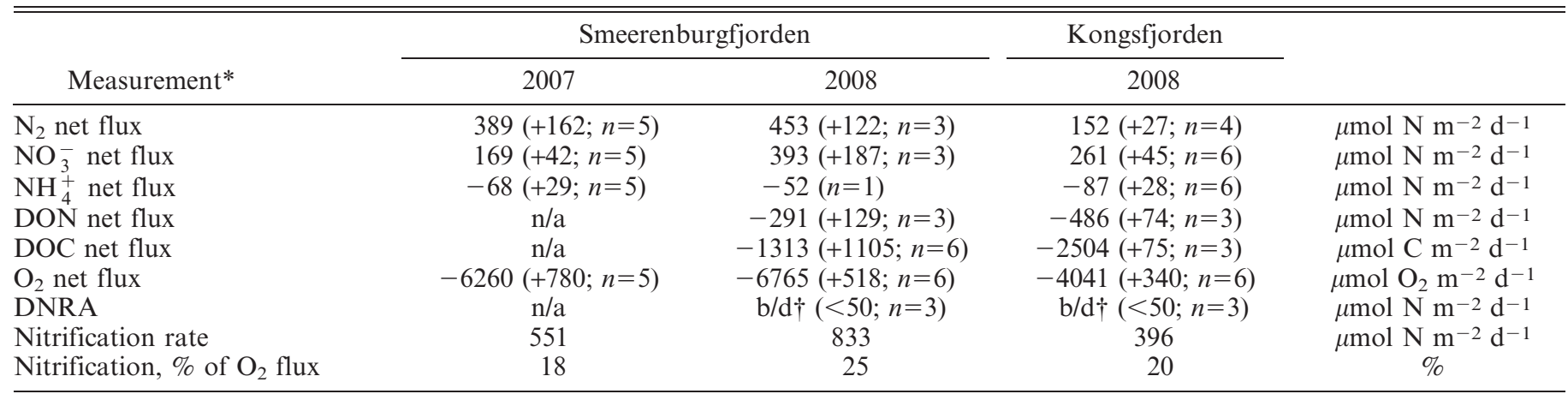

\footnotetext{
* DON $=$ dissolved organic nitrogen; DOC $=$ dissolved organic carbon; DNRA $=$ dissimilatory nitrate reduction to ammonium.
}

$\dagger \mathrm{b} / \mathrm{d}=$ below detection. 
Table 5. Rates determined using isotope tracer core and slurry incubations. Reported errors for gross $\mathrm{N}_{2}$ production, denitrification, and anammox rates in cores were derived from standard errors of the regression coefficients. Error for the acetylene reduction assay is the standard error of replicate slurries.

\begin{tabular}{|c|c|c|c|}
\hline \multirow[b]{2}{*}{ Measurement (Unit)* } & \multicolumn{2}{|c|}{ Smeerenburgfjorden } & \multirow{2}{*}{$\frac{\text { Kongsfjorden }}{2008}$} \\
\hline & 2007 & 2008 & \\
\hline \multicolumn{4}{|l|}{$15 \mathrm{NO}_{3}^{-}$cores: } \\
\hline $\mathrm{p}_{14}\left(\mu \mathrm{mol} \mathrm{N} \mathrm{m} \mathrm{N}^{-2} \mathrm{~d}^{-1}\right)$ & $320(+25)$ & $305(+4.9)$ & $44(+16)$ \\
\hline Anammox rate $\left(\mu \mathrm{mol} \mathrm{N} \mathrm{m}^{-2} \mathrm{~d}^{-1}\right)$ & $26(+2.0)$ & $15(+0.2)$ & $10(+3.6)$ \\
\hline Denitrification rate $\left(\mu \mathrm{mol} \mathrm{N} \mathrm{m}-2 \mathrm{~d}^{-1}\right)$ & $294(+23)$ & $289(+4.6)$ & $34(+12)$ \\
\hline Denitr. $\%$ of carbon oxidation $(\%)$ & 4 & 4 & 1 \\
\hline \multicolumn{4}{|l|}{$15 \mathrm{NH}_{4}^{+}$cores: } \\
\hline Anammox potential rate $\left(\mu \mathrm{mol} \mathrm{N} \mathrm{cm}^{-3} \mathrm{~d}^{-1}\right)$ & $81(+7)$ & $46(+2)$ & $17(+1)$ \\
\hline \multicolumn{4}{|l|}{${ }^{15} \mathrm{NO}_{3}^{-}$slurries $(0-5 \mathrm{~cm}$, integrated $):$} \\
\hline Anammox potential rate $\left(\mathrm{nmol} \mathrm{N} \mathrm{cm}^{-3} \mathrm{~d}^{-1}\right)$ & 7.5 & 1.8 & 10 \\
\hline Denitrification potential rate $\left(\mathrm{nmol} \mathrm{N} \mathrm{cm}^{-3} \mathrm{~d}^{-1}\right)$ & 74 & 33 & 33 \\
\hline Anammox $(\mathrm{ra} ; \%)$ & 8 & 5 & 23 \\
\hline \multicolumn{4}{|l|}{ Acetylene reduction assays: } \\
\hline $\mathrm{N}_{2}$ fixation potential rate $\left(\mu \mathrm{mol} \mathrm{N} \mathrm{m}-2 \mathrm{~d}^{-1}\right)$ & $\mathrm{n} / \mathrm{a} \uparrow$ & $20(+2 ; n=5)$ & $<1(n=5)$ \\
\hline
\end{tabular}

$* \mathrm{p}_{14}=$ gross ${ }^{14} \mathrm{~N}-\mathrm{N}_{2}$ production rate; ra $=$ contribution of anammox to total $\mathrm{N}_{2}$ production determined in slurries.

$\dagger \mathrm{n} / \mathrm{a}=$ not analyzed.

benthic respiration pathways determined in Svalbard fjords (Arnosti et al. 1998; Vandieken et al. 2006). Previous work characterizing carbon and nitrogen compositions within Svalbard fjord surface sediments has suggested that benthic organic matter is mainly of terrestrial origin; however, refractory organic matter did not appear to accumulate in sediments (Hulth et al. 1994; Knies et al. 2007). Sediment organic carbon contents determined here $(0.30-1.45 \%$; Table 2) were comparable to that of many continental slope (Meyers 1997; Schulz and Zabel 2000) and Spitsbergen shelf (Knies et al. 2007) sediments. Total nitrogen

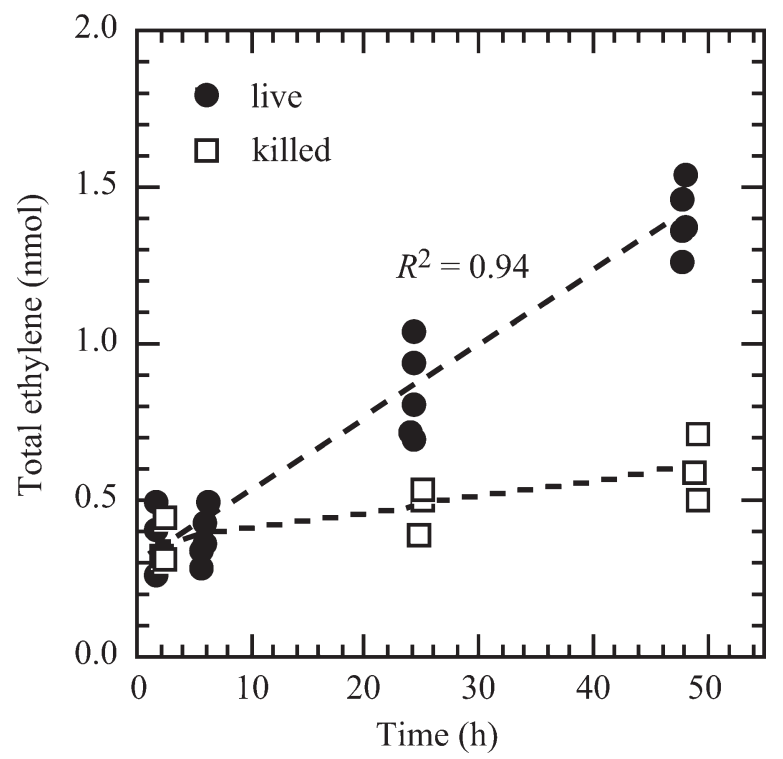

Fig. 4. Time course of total ethylene determined in Smeerenburgfjorden sediment live and killed slurry incubations. The linear fit of five replicate live slurries was used to calculate $\mathrm{N}_{2}$ fixation rates. values at the two sites contrasted somewhat, resulting in lower levels of nitrogen relative to carbon in the Kongsfjorden sediment (C:N 11) compared to Smeerenburgfjorden ( $\mathrm{C}: \mathrm{N}$ 7.2). High-sediment $\mathrm{C}: \mathrm{N}$ ratios may be indicative of extensive diagenetic alteration of particulate organic matter (POM; Hedges et al. [1997]; Meyers [1997]), suggesting the POM at Kongsfjorden may be highly refractory, or may be indicative of terrestrial detritus input, which commonly has higher $\mathrm{C}: \mathrm{N}$ than marine particulate material (Thornton and Mcmanus 1994; Meyers 1997). Future work analyzing natural abundance stable isotopes of carbon and nitrogen in these sediments may provide further insight as to the detrital sources (Knies et al. 2007). The ratios of $\mathrm{C}: \mathrm{N}$ in Smeerenburgfjorden sediment (7.2) were similar to that expected from marine plankton or seagrass detritus (Meyers 1997), suggesting the detritus deposited is primarily labile organic carbon. Although the deposition of marine POM in western Svalbard fjords mainly occurs only once per year following the spring phytoplankton bloom (Hop et al. 2002), annual water column production along the western and southern coasts of Svalbard is high, estimated at up to $150 \mathrm{~g} \mathrm{C} \mathrm{m}^{-2} \mathrm{yr}^{-1}$ (Eilertsen et al. 1989). Therefore, it is likely that denitrification rates may vary temporally in response to both seasonal terrigenous runoff and marine phytodetritus deposition events at these sites.

Acetylene reduction assays demonstrated the presence of nitrogenase activity at the Smeerenburgfjorden site (Fig. 5). Extrapolation of the acetylene reduction rates in slurry incubations suggests an approximate $\mathrm{N}_{2}$ fixation potential rate of $20 \mu \mathrm{mol} \mathrm{N} \mathrm{m}-2 \mathrm{~d}^{-1}$. This rate is comparable to $\mathrm{N}_{2}$ fixation rates reported from temperate shelf sediments (see review by Capone 1988) and is 4-20-fold higher than measurements from the Beaufort Sea north of Alaska (1$5 \mu \mathrm{mol} \mathrm{N} \mathrm{m}{ }^{-2} \mathrm{~d}^{-1}$; Knowles and Wishart [1977]; Haines et al. [1981]). Nitrogen fixation is a common trait of heterotrophic 

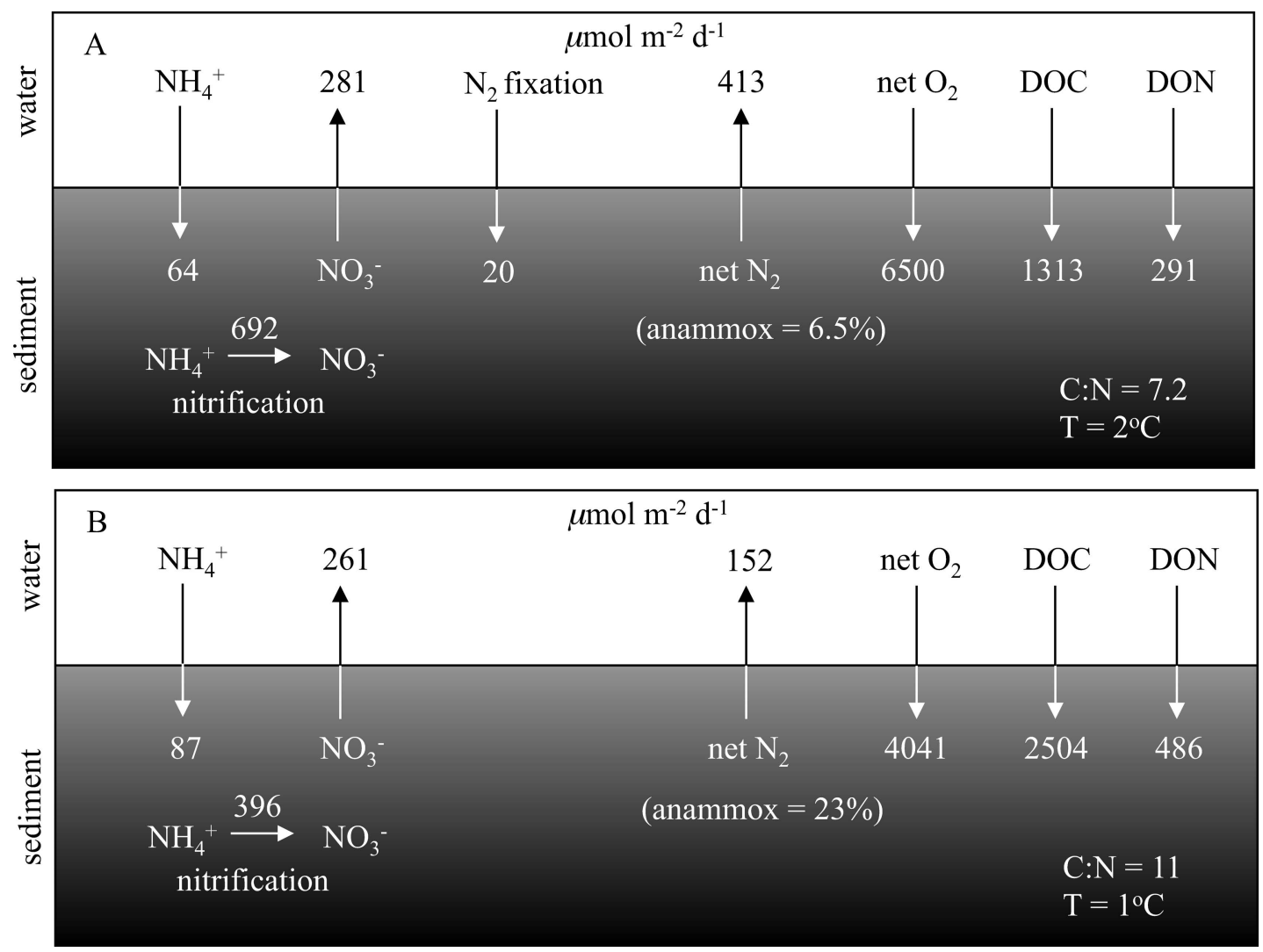

Fig. 5. Summary diagram showing mean rates and sediment-water interface fluxes for (A) Smeerenburgfjorden and (B) Kongsfjorden.

bacteria that mediate denitrification and sulfate reduction, both of which are important respiration pathways in Svalbard fjords (Kostka et al. 1999). Thus $\mathrm{N}_{2}$-fixing, sulfateor nitrate-reducing populations may play a role in net $\mathrm{N}_{2}$ fluxes at the Smeerenburgfjorden site where nitrogenase activity was detected. Future work to identify the diazotrophic taxa and to directly determine $\mathrm{N}_{2}$ fixation rates under near in situ conditions is required to further elucidate the role of $\mathrm{N}_{2}$ uptake in the net balance of $\mathrm{N}_{2}$ at the these site.

Anammox - Results demonstrating anaerobic ammonium oxidation activity in Svalbard fjord sediments are among the first reported anammox rates in the Arctic and further extend the known occurrence of this process in marine environments. The detection of anammox here corresponds well with the confirmed presence of abundant Planctomycetes (Ravenschlag et al. 1999, 2001), taxa known to catalyze anammox (Strous et al. 1999; Kuypers et al. 2003). The combined application of ${ }^{15} \mathrm{NO}_{3}^{-}$amendments with ${ }^{29} \mathrm{~N}_{2}$ and ${ }^{30} \mathrm{~N}_{2}$ detection in cores and slurries showed rates of $\mathrm{N}_{2}$ production via anammox slightly higher at the Smeerenburgfjorden site (15-26 $\left.\mu \mathrm{mol} \mathrm{N} \mathrm{m} \mathrm{N}^{-2} \mathrm{~d}^{-1}\right)$ compared to Kongsfjorden $\left(10 \mu \mathrm{mol} \mathrm{N} \mathrm{m}{ }^{-2} \mathrm{~d}^{-1}\right)$. However, at Kongsfjorden, where observed denitrification rates were substantially lower, anammox comprised a larger portion of gross $\mathrm{N}_{2}$ production ( $23 \%$ of total $\mathrm{N}_{2}$ ) compared to the Smeerenburgfjorden site (5-8\%). Experiments conducted here demonstrating anammox activity within intact sediment cores by ${ }^{15} \mathrm{NH}_{4}^{+}$conversion to ${ }^{29} \mathrm{~N}_{2}$ under nitrification inhibition (Thamdrup and Dalsgaard 2002) provided an added measure that qualitatively confirmed anammox at both sites under near in situ conditions. These rates and percentages for Svalbard sediments are comparable to those measured by Rysgaard et al. (2004) in Greenland coastal sediments $\left(1-92 \mu \mathrm{mol} \mathrm{N} \mathrm{m}{ }^{-2} \mathrm{~d}^{-1} ; 1-\right.$ $35 \%$ of total $\mathrm{N}_{2}$ ), the only other study to quantify anammox in Arctic sediments.

In a review of marine anammox, Dalsgaard et al. (2005) noted that overall anammox rates are generally higher in shallow, organic-rich coastal sediments but also noted an inverse, linear correlation between mineralization rates and the contribution of anammox to total $\mathrm{N}_{2}$ production in deeper sediments. Possible explanations for these trends were: sediments with higher organic content have higher production of nitrite, the limiting substrate; and, denitrification as a percent of $\mathrm{N}_{2}$ generation is suppressed in deepwater environments with lower rates of organic substrate deposition (Dalsgaard et al. 2005). A positive correlation of relative anammox contributions with bottom-water nitrate concentrations has also been noted (Rysgaard et al. 2004), although a clear explanation of this observation remains elusive (Dalsgaard et al. 2005).

The mechanisms controlling anammox proposed by Dalsgaard et al. (2005) may be invoked in the present study. At Kongsfjorden, denitrification as a percent of $\mathrm{N}_{2}$ generation (as well as overall benthic respiration) is 
suppressed, likely due to limited labile organic matter availability. Thus, although anammox rates are low, the contribution to $\mathrm{N}_{2}$ production is relatively high. Carbon oxidation rates are higher at Smeerenburgfjorden compared to Kongsfjorden, as indicated by oxygen uptake (Table 4) and sulfate reduction rates (B. B. Jørgensen unpubl.); higher carbon turnover at Smeerenburgfjorden likely leads to higher rates of nitrification and denitrification, which may in turn provide sufficient $\mathrm{NO}_{2}^{-}$for utilization by anammox bacteria (Meyer et al. 2005). Therefore, although the contribution anammox to total $\mathrm{N}_{2}$ production is less at Smeerenburgfjorden, overall rates of anammox are higher than at Kongsfjorden. Vertical profiling of the Smeerenburgfjorden sediment confirmed a maximum in anammox activity at $1-2 \mathrm{~cm}$ (Fig. 4), in proximity to the zone where ammonium and nitrate concentrations are both relatively high and nitrite is likely being produced from nitrification or denitrification (Fig. 2). The general occurrence of anammox in Svalbard sediments is also likely the result of stable and permanently cold conditions, because anammox populations are better adapted to cold temperatures over denitrifying communities (Rysgaard et al. 2004).

Nitrification and pore-water profiles-The production of nitrate by means of nitrification clearly outpaced the demand from denitrification and anammox as nitrate effluxes approached $400 \mu \mathrm{mol} \mathrm{N} \mathrm{m}{ }^{-2} \mathrm{~d}^{-1}$ (Table 4). Gross nitrification rates reached $833 \mu \mathrm{mol} \mathrm{N} \mathrm{m}^{-2} \mathrm{~d}^{-1}$ and diffusive ammonium loss to the overlying water was completely prevented at both sites. As a percentage of total oxygen consumption (20-25\%), the contribution of nitrification was comparable to that determined for Western Arctic (27\%; Devol et al. 1997) and many temperate (20-30\%; Laursen and Seitzinger 2002) coastal sediments. Depth profiles of DIN indicated substantially more ammonium accumulation in Smeerenburgfjorden pore-waters in comparison to those at Kongsfjorden, consistent with the higher $\mathrm{O}_{2}$ respiration and organic matter mineralization rates observed at the Smeerenburgfjorden site. Depth profiles from both sites showed increases in nitrate in the surface layers concomitant with ammonium depletion, a clear indication of nitrification activity. Thamdrup and Fleischer (1998) also observed extensive nitrification in coastal Svalbard sediments, and demonstrated that nitrifiers are particularly well-adapted to cold temperatures. The presence of nitrate peaks in zones $>4$ $\mathrm{cm}$ depth, particularly in the Kongsfjorden profiles, were likely due to oxygenation and stimulation of nitrification activity from bioirrigation of tube worm burrows, further underlining the influence of abundant benthic fauna on biogeochemical processes in Svalbard fjords (Glud et al. 1998; Kostka et al. 1999). The lack of nitrate accumulation in two of the Smeerenburgfjorden profiles may have been the result of either variability in faunal density or heterogeneity in nitrate consumption via $\mathrm{N}_{2}$ production in those locations. Nitrite accumulation was not observed in pore-water profiles suggesting that consumption of nitrite during anammox and denitrification, or rapid nitrification to nitrate, maintained low levels of pore-water nitrite.
Dissolved organic carbon and nitrogen fluxes-Flux determinations demonstrated substantial influx of DON across the sediment-water interface of both sites, particularly at Kongsfjorden where DON uptake dominated the balance of dissolved nitrogen fluxes. Water-column DON concentrations can often exceed DIN concentrations in marine systems, and DON is typically dominated by a pool of highmolecular-weight polysaccharides (e.g., chitin and peptidoglycan) and humic substances, which are considered largely resistant to biological degradation (Bronk et al. 2007). The less abundant DON fractions, comprised of smaller, labile compounds (e.g., urea and free amino acids) with much faster turnover, serve as important substrates for microbial growth and sources of nitrogen for marine primary production (Bronk et al. 2007). Determinations of the composition and sources, and differentiation between heterotrophic and autotrophic utilization, of DON in Svalbard fjords are beyond the scope of this study. However, the observed uptake suggests that DON is a potentially important source of nitrogen for benthic organisms. Mineralization of DON may also be important in sustaining the observed high rates of nitrification, which in turn fuels denitrification and returns DIN into the water column. Observed ratios of DOC to DON influx (4.5 and 5.2 at Smeerenburgfjorden and Kongsfjorden, respectively) lower than the Redfield C:N of 6.6 for particulate organic matter may have been the result of preferential utilization of DOM rich in nitrogen relative to the bulk pool, a process observed in other marine environments (Hopkinson and Vallino 2005).

Although quantifying benthic DOC fluxes was not the main focus of this study, and measured rates were variable, the observation of substantial DOC consumption is nonetheless intriguing. The Arctic Ocean receives large volumes of terrestrial discharge rich in DOC, which persists due to a perceived absence of practical sinks in Arctic estuarine or shelf environments, as evidenced by conservative mixing in these systems (Dittmar and Kattner 2003). On the other hand, recent work has demonstrated that most riverine DOC exported to the Arctic Ocean is relatively young and presumably semi-labile (Raymond et al. 2007). Results presented here showing DOC uptake by fjord sediments appear to contradict the general view of DOM preservation and recalcitrance in the Arctic Ocean. DOC uptake rates were 19\% (Smeerenburgfjorden) to $62 \%$ (Kongsfjorden) of total $\mathrm{O}_{2}$ consumption, suggesting a substantial role of DOC in benthic respiration at these sites. These preliminary data identify that further uptake rate measurements, the determination of DOC and DON compositions, and potential sources of DOM pools in Svalbard fjords are warranted.

By determining sediment-water fluxes, and quantifying multiple transformation pathways, we provide new insights into the nitrogen cycle of the Arctic seafloor. Our results demonstrate that benthic $\mathrm{N}_{2}$ production in Svalbard fjords is dominated by denitrification and net $\mathrm{N}_{2}$ fluxes are comparable to those determined for temperate coastal regions. Although anammox has been largely unrecognized in previous Arctic studies, our results confirm that anammox is an important pathway for $\mathrm{N}_{2}$ production. Evidence presented here suggests that gross $\mathrm{N}_{2}$ production 
may be partly compensated by nitrogen fixation at one of the sites. Sediments were a substantial source of nitrate to the water column, which may affect bottom-water DIN loads of the Arctic Basin and North Atlantic. Future work is necessary to assess seasonal changes in benthic nitrogen cycling rates and pathways, to confirm the extent of $\mathrm{N}_{2}$ fixation, and to further explore the role of benthic DOC and DON uptake.

\section{Acknowledgments}

We thank captain Stig Henningsen and the crew of R/V FARM for their assistance with sample collection, and acknowledge Casey Hubert, Bo Barker Jørgensen, Timothy Ferdelman, Carol Arnosti, Drew Steen, Joanna Sawicka, Hani Tahsk, Gabriele Klockgether, Elin Austerheim, Dave Oliff, Ashley Riggs, Andy Canion, Cedric Magen, Jeff Cornwell, Mike Owens, Wayne Gardner, Mark McCarthy, and Yingfeng Xu for field sampling, logistical, and analytical assistance. We also thank two anonymous reviewers for their valuable comments. This study was supported by the Max Planck Society and the National Science Foundation. T. M. G. was supported in part by a fellowship from the Estuarine Reserves Division, Office of Ocean and Coastal Resource Management, National Oceanic and Atmospheric Administration. Partial support was provided to J. E. K. by the Hanse Wissenschaftskolleg.

\section{References}

An, S., W. S. Gardner, And T. Kana. 2001. Simultaneous measurement of denitrification and nitrogen fixation using isotope pairing with membrane inlet mass spectrometry analysis. Appl. Environ. Microbiol. 67: 1171-1178.

Arnosti, C., B. B. Jorgensen, J. Sagemann, and B. Thamdrup. 1998. Temperature dependence of microbial degradation of organic matter in marine sediments: Polysaccharide hydrolysis, oxygen consumption, and sulfate reduction. Mar. Ecol.Prog. Ser. 165: 59-70.

Arrigo, K. R., G. van Dijken, and S. Pabi. 2008. Impact of a shrinking Arctic ice cover on marine primary production. Geophys. Res. Lett. 35: L19603, doi:10.1029/2008GL035028.

Blackburn, T. H., P. O. J. Hall, S. Hulth, and A. Landen. 1996. Organic-N loss by efflux and burial associated with a low efflux of inorganic $\mathrm{N}$ and with nitrate assimilation in Arctic sediments (Svalbard, Norway). Mar. Ecol.-Prog. Ser. 141: 283-293.

Bower, C. E., And T. Holm-Hansen. 1980. A salicylatehypochlorite method for determining ammonia in seawater. Can. J. Fish. Aquat. Sci. 37: 794-798.

Braman, R., AND S. HendRIX. 1989. Nanogram nitrite and nitrate determination in environmental and biological materials by vanadium(III) reduction with chemiluminescence detection. Anal. Chem. 61: 2715-2718.

Bronk, D. A., J. H. See, P. Bradley, and L. Killberg. 2007. DON as a source of bioavailable nitrogen for phytoplankton. Biogeosciences 4: 283-296.

CANField, D. E., AND others. 1993. Pathways of organic carbon oxidation in three continental margin sediments. Mar. Geol. 113: $27-40$.

CAPONE, D. G. 1988. Benthic nitrogen fixation, p. 85-123. In T. H. Blackburn and J. Sorensen [eds.], Nitrogen cycling in coastal marine environments. Wiley \& Sons.

1993. Determination of nitrogenase activity in aquatic samples using the acetylene reduction procedure, p. 621-631. In P. F. Kemp, B. F. Sherr, E. B. Sherr and J. J. Cole [eds.], Handbook of methods in aquatic microbial ecology. Lewis.
Chang, B. X., and A. H. Devol. 2009. Seasonal and spatial patterns of sedimentary denitrification rates in the Chukchi Sea. Deep-Sea Res. II 56: 1339-1350.

Christensen, J. P., J. W. Murray, A. H. Devol, and L. A. Codispoti. 1987. Denitrification in continental shelf sediments has major impact on the oceanic nitrogen budget. Glob. Biogeochem. Cycles 1: 97-116.

Cornwell, J. C., W. M. Kemp, and T. M. Kana. 1999. Denitrification in coastal ecosystems: Methods, environmental controls, and ecosystem level controls, a review. Aquat. Ecol. 33: 41-54.

Cottier, F., V. Tverberg, M. Inall, H. Svendsen, F. Nilsen, and C. GRIfFiths. 2005. Water mass modification in an Arctic fjord through cross-shelf exchange: The seasonal hydrography of Kongsfjorden, Svalbard. J. Geophys. Res.-Oceans 110: C12005, doi:10.1029/2004JC002757.

Dalsgand, T., B. Thamdrup, and D. E. Canfield. 2005. Anaerobic ammonium oxidation (anammox) in the marine environment. Res. Microbiol. 156: 457-464.

Devol, A. H., L. A. Codispoti, and J. P. Christensen. 1997. Summer and winter denitrification rates in western Arctic shelf sediments. Continent. Shelf Res. 17: 1029-1050.

Dittmar, T., AND G. Kattner. 2003. The biogeochemistry of the river and shelf ecosystem of the Arctic Ocean: A review. Mar. Chem. 83: 103-120.

Eilertsen, H. C., J. P. TaAsen, and J. M. Weslawski. 1989. Phytoplankton studies in the fjords of west Spitzbergenphysical-environment and production in spring and summer. J. Plankton Res. 11: 1245-1260.

Eyre, B. D., S. Rysgaard, T. Dalsgaard, and P. B. Christensen. 2002. Comparison of isotope pairing and $\mathrm{N}_{2}$ : Ar methods for measuring sediment-denitrification-assumptions, modifications, and implications. Estuaries 25: 1077-1087.

Gardner, W. S., H. A. Bootsma, C. Evans, and P. A. S. John. 1995. Improved chromatographic analysis of N-15-N-14 ratios in ammonium or nitrate for isotope addition experiments. Mar. Chem. 48: 271-282.

Garside, C. 1982. A chemiluminescent technique for the determination of nanomolar concentrations of nitrate and nitrite in seawater. Mar. Chem. 11: 159-167.

Glud, R. N., O. Holby, F. Hoffmann, and D. E. Canfield. 1998. Benthic mineralization and exchange in Arctic sediments (Svalbard, Norway). Mar. Ecol.-Prog. Ser. 173: 237-251. , N. Risgaard-Petersen, B. Thamdrup, H. Fossing, and S. RYSGAARD. 2000. Benthic carbon mineralization in a highArctic sound (Young Sound, NE Greenland). Mar. Ecol.Prog. Ser. 206: 59-71.

Grasshoff, K., M. Ehrhardt, and K. Kremling. 1983. Methods of seawater analysis, 2nd revised and extended ed. Verlag Chemie/Academic Press.

Grebmeier, J. M., And C. P. McRoy. 1989. Pelagic-benthic coupling on the shelf of the northern Bering and Chukchi Seas. 3. Benthic food-supply and carbon cycling. Mar. Ecol.Prog. Ser. 53: 79-91.

Haines, J. R., R. M. Atlas, R. P. Griffiths, and R. Y. Morita. 1981. Denitrification and Nitrogen Fixation in Alaskan Continental Shelf Sediments. Appl. Environ. Microbiol. 41: $412-421$.

Hall, G. H. 1984. Measurement of nitrification rates in lake sediments: Comparison of the nitrification inhibitors nitrapyrin and allylthiourea. Microbial Ecology. 10: 25-36.

Hansell, D. A., And J. J. Goering. 1990. Pelagic nitrogen flux in the northern Bering Sea. Continent. Shelf Res. 10: 501-519.

Hedges, J. I., R. G. Keil, And R. Benner. 1997. What happens to terrestrial organic matter in the ocean? Org. Geochem. 27: $195-212$. 
, AND J. H. STERn. 1984. Carbon and nitrogen determinations of carbonate-containing solids. Limnol. Oceanogr. 29: $657-663$.

Henriksen, K., T. H. Blackburn, B. A. Lomstein, and C. P. McRoy. 1993. Rates of nitrification, distribution of nitrifying bacteria and inorganic $\mathrm{N}$ fluxes in northern Bering-Chukchi shelf sediments. Continent. Shelf Res. 13: 629-651.

Hop, H., AND OTHERs. 2002. The marine ecosystem of Kongsfjorden, Svalbard. Polar Res. 21: 167-208.

Hopkinson, C. S., AND J. J. VAllino. 2005. Efficient export of carbon to the deep ocean through dissolved organic matter. Nature 433: 142-145.

Hulth, S., T. H. Blackburn, and P. O. J. Hall. 1994. Arctic sediments (Svalbard) - consumption and microdistribution of oxygen. Mar. Chem. 46: 293-316.

Jensen, M. M., B. Thamdrup, And T. Dalsgaard. 2007. Effects of specific inhibitors on anarnmox and denitrification in marine sedirnents. Appl. Environ. Microbiol. 73: 3151-3158.

Kana, T. M., C. Darkangelo, M. D. Hunt, J. B. Oldham, G. E. Bennett, and J. C. Cornwell. 1994. Membrane inlet mass spectrometer for rapid high-precision determination of $\mathrm{N}_{2}$, $\mathrm{O}_{2}$, and $\mathrm{Ar}$ in environmental water samples. Anal. Chem. 66: 4166-4170.

Kanneworff, E., And W. Nicolaisen. 1973. The 'Haps', a frame supported bottom corer. Ophelia 10: 119-128.

KarL, D., AND others. 2002. Dinitrogen fixation in the world's oceans. Biogeochemistry 57/58: 47-98.

Knies, J., S. Brookes, And C. J. Schubert. 2007. Re-assessing the nitrogen signal in continental margin sediments: New insights from the high northern latitudes. Earth Planet. Sci. Lett. 253: 471-484.

Knowles, R., and C. Wishart. 1977. Nitrogen fixation in arctic marine sediments: Effect of oil and hydrocarbon fractions. Environ. Pollut. (1970) 13: 133-149.

Kostka, J. E., B. Thamdrup, R. N. Glud, and D. E. Canfield. 1999. Rates and pathways of carbon oxidation in permanently cold Arctic sediments. Mar. Ecol.-Prog. Ser. 180: 7-21.

Kuypers, M. M. M., AND others. 2003. Anaerobic ammonium oxidation by anammox bacteria in the Black Sea. Nature 422: $608-611$.

Laursen, A. E., and S. P. Seitzinger. 2002. The role of denitrification in nitrogen removal and carbon mineralization in Mid-Atlantic Bight sediments. Cont. Shelf Res. 22: 1397-1416.

Manley, T. O. 1995. Branching of Atlantic Water within the Greenland-Spitsbergen passage: An estimate of recirculation. J. Geophys. Res. 100: 20,627-20,634.

Meyer, R. L., N. Risgaard-Petersen, and D. E. Allen. 2005. Correlation between anammox activity and microscale distribution of nitrite in a subtropical mangrove sediment. Appl. Environ. Microbiol. 71: 6142-6149.

Meyers, P. A. 1997. Organic geochemical proxies of paleoceanographic, paleolimnologic, and paleoclimatic processes. Org. Geochem. 27: 213-250.

Nielsen, L. P. 1992. Denitrification in sediment determined from nitrogen isotope pairing. FEMS Microbiol. Ecol. 86: 357-362.

Ravenschlag, K., K. Sahm, J. Pernthaler, and R. Amann. 1999. High bacterial diversity in permanently cold marine sediments. Appl. Environ. Microbiol. 65: 3982-3989.

- - AND R. AmAnN. 2001. Quantitative molecular analysis of the microbial community in marine Arctic sediments (Svalbard). Appl. Environ. Microbiol. 67: 387-395.
RAymond, P. A., AND others. 2007. Flux and age of dissolved organic carbon exported to the Arctic Ocean: A carbon isotopic study of the five largest arctic rivers. Glob. Biogeochem. Cycle 21: GB4011, doi:10.1029/2007GB002934.

Risgaard-Petersen, N., L. P. Nielsen, S. Rysgaard, T. Dalsgando, and R. L. Meyer. 2003. Application of the isotope pairing technique in sediments where anammox and denitrification co-exist. Limnol. Oceanogr. Meth. 1: 63-73.

Rudels, B., R. Meyer, E. Fahrbach, V. Ivanov, S. Osterhus, D. Quadfasel, U. Schauer, V. Tverberg, and R. A. Woodgate. 2000. Water mass distribution in Fram Strait and over the Yermak Plateau in summer 1997, Annales Geophysicae 18: 687-705.

Rysgaard, S., K. Finster, and H. Dahlgaard. 1996. Primary production, nutrient dynamics and mineralization in a northeastern Greenland fjord during the summer thaw. Polar Biol. 16: 497-506.

- R. N. Glud, N. Risgaard-Petersen, and T. Dalsgaard 2004. Denitrification and anammox activity in Arctic marine sediments. Limnol. Oceanogr. 49: 1493-1502.

- B. Thamdrup, N. Risgaard-Petersen, H. Fossing, P. Berg, P. B. Christensen, And T. Dalsganad. 1998. Seasonal carbon and nutrient mineralization in a high-Arctic coastal marine sediment, Young Sound, Northeast Greenland. Mar. Ecol.-Prog. Ser. 175: 261-276.

Schulz, H. D., AND M. ZABel. 2000. Marine geochemistry. Springer.

Seeberg-Elverfeldt, J., M. Schluter, T. Feseker, and M. Kolling. 2005. Rhizon sampling of porewaters near the sediment-water interface of aquatic systems. Limnol. Oceanogr. Meth. 3: 361-371.

Seitzinger, S. P., And A. E. Giblin. 1996. Estimating denitrification in North Atlantic continental shelf sediments. Biogeochem. 35: 235-260.

Strous, M., J. G. Kuenen, and M. S. M. Jetten. 1999. Key physiology of anaerobic ammonium oxidation. Appl. Environ. Microbiol. 65: 3248-3250.

Thamdrup, B., And T. Dalsgand. 2002. Production of $\mathrm{N}_{2}$ through anaerobic ammonium oxidation coupled to nitrate reduction in marine sediments. Appl. Environ. Microbiol. 68: 1312-1318.

—, AND S. Fleischer. 1998. Temperature dependence of oxygen respiration, nitrogen mineralization, and nitrification in Arctic sediments. Aquat. Microb. Ecol. 15: 191-199.

Thornton, S. F., And J. McManus. 1994. Application of organic carbon and nitrogen stable isotope and $\mathrm{C} / \mathrm{N}$ ratios as source indicators of organic matter provenance in estuarine systems: evidence from the Tay estuary, Scotland. Estuar. Coast. Shelf Sci. 38: 219-233.

Wassmann, P. 1991. Dynamics of primary production and sedimentation in shallow fjords and polls of western Norway. Oceanogr. Mar. Biol. 29: 87-154.

Yamamoto-Kawai, M., E. Carmack, and F. McLaughlin. 2006. Nitrogen balance and Arctic throughflow. Nature 443: 43-43.

Associate editor: Samantha B. Joye

Received: 31 March 2009 Accepted: 04 December 2009 Amended: 04 December 2009 